\title{
Perspektiva NEET populacije u urbanoj aglomeraciji Zagreb prema percepciji stručnjaka i mladih u NEET statusu - kako im pomoći?
}

\author{
Danijel Baturina \\ Pravni fakultet Sveučilišta u Zagrebu, Studijski centar socijalnog rada, Hrvatska \\ e-mail: danijel.baturina@pravo.hr
}

\author{
Marijana Majdak \\ Pravni fakultet Sveučilišta u Zagrebu, Studijski centar socijalnog rada, Hrvatska \\ e-mail:marijana.majdak@pravo.hr
}

\section{Gordana Berc \\ Pravni fakultet Sveučilišta u Zagrebu, Studijski centar socijalnog rada, Hrvatska e-mail:gordana.berc@pravo.hr}

SAŽETAK Zbog velike zastupljenosti NEET (engl. Not in Education, Employment, or Training) populacije Europska je unija 2013. godine izradila operativni plan smanjivanja njenog udjela za period 2014. - 2020. godine. U Hrvatskoj su također planirane mjere i sredstva Europskog socijalnog fonda trebala osigurati različite resurse na državnoj i lokalnoj razini za realizaciju istog cilja. Grad Zagreb u okviru ulaganja u socijalnu politiku razvija brojne usluge i programe, osobito za mlade u nepovoljnom položaju. Ovo kvalitativno istraživanje usmjereno je na stjecanje uvida u iskustva stručnjaka i pripadnika NEET populacije o uslugama i programima usmjerenih prema NEET populaciji na području Grada Zagreba u svrhu njihove pripreme za zapošljavanje te na percepciju o mogućim poboljšanjima usluga i prevenciji NEET statusa. U istraživanju je sudjelovalo 15 stručnjaka koji rade s NEET populacijom i 25 pripadnika NEET populacije. Rezultati ukazuju na to da stručnjaci prepoznaju velike izazove u radu s NEET populacijom vezane uz motiviranje mladih na promjenu i na zahtjevne modele rada. Osim toga, izdvojene su institucionalne manjkavosti poput nedovoljne koordinacije s drugim institucijama, administrativnih ograničenja i nedovoljne osposobljenosti stručnjaka, što prepoznaju obje grupe sudionika istraživanja. Mladi naglašavaju da su im neke usluge i informacije koje dobivaju od stručnjaka nekorisne i zakašnjele, a s druge strane da imaju pozitivna iskustva u dobivanju stručnih preporuka i osobne podrške. Istraživanje ukazuje na potrebu za sustavnim ulaganjem u institucije koje rade s NEET populacijom (kadrovi, prostor, informatizacija, koordinacija institucija) na području Grada Zagreba. Također je naglašena potreba poboljšanja sadržaja i modela rada programa te promocije i dostupnosti programa podrške NEET populaciji radi njihovog uključivanja na tržište rada.

Ključne riječi: NEET populacija, stručnjaci, urbana aglomeracija Zagreb, socijalna politika, nezaposlenost, programi i mjere poticanja zapošljavanja NEET populacije.

Copyright (C) 2020 Institut za društvena istraživanja u Zagrebu - Institute for Social Research in Zagreb Sva prava pridržana - All rights reserved 


\section{Uvod}

Termin NEET prvi se put pojavio 1990-ih godina u Velikoj Britaniji tijekom političkih rasprava oko potrebe za reintegracijom mladih osoba u dobi od 16 do 18 godina ${ }^{1}$ koje su napustile obrazovanje, a nisu se uključile na tržište rada (Eurofound, 2016.). U široj je upotrebi od 2010. godine, kada se Odbor za zapošljavanje (EMCO) Europske komisije usuglasio da će se u kontekstu Smjernica za zapošljavanje Strategije Europa 2020. usredotočiti upravo na NEET populaciju (Operativni program Učinkoviti ljudski potencijali, 2014.).

NEET populacija postala je jedan od prioriteta Europske unije s obzirom na njenu zastupljenost u populaciji, što je pokrenulo inicijativu za kreiranjem Operativnog programa Učinkoviti ljudski potencijali 2014. - 2020. Podaci Eurostata za 2013. godinu pokazuju da je prosječni udio mladih od 19 do 34 godine koji nisu uključeni u obrazovanje, zaposlenje ili programe osposobljavanja za zemlje članice Europske unije bio $17,2 \%$, a u Hrvatskoj 23,2\%, dok su neke zemlje u toj godini bilježile više postotke (Grčka 30,8\%, Italija 27,2\%, Španjolska 24\%) (Eurostat, 2020.a). Smanjenje udjela NEET populacije jedan je od jasnih ciljeva Garancije za mlade, inicijative EU-a iz 2013. godine. Prema operativnom programu Hrvatska ima obvezu provesti Plan implementacije Garancije za mlade (PIGzM) u cijelosti u sklopu svojih investicijskih prioriteta, koji su osobito usmjereni na integraciju NEET populacije na tržište rada (Operativni program Učinkoviti ljudski potencijali 2014. - 2020.). Budući da Operativni program Učinkoviti ljudski potencijali 2014. - 2020. obvezuje svaku članicu da poduzme određene mjere i reforme kako bi se smanjio udio NEET-a, neke zemlje do 2019. godine bilježe pad zastupljenosti NEET populacije. Tako podaci Eurostata pokazuju da je na razini prosjeka Unije zabilježeno $14 \%$, ili oko 5 milijuna pripadnika NEET populacije, dok je za Hrvatsku registrirano $15 \%$ te populacije, a to je ponovno iznad europskog prosjeka, što vrijedi i za Grčku (20,7\%), Italiju (23,8\%) i Španjolsku $(16,0 \%)$ (Eurostat, 2020.a) ${ }^{2}$.

Te brojke zaokupljaju interes znanstvene i stručne zajednice. Tako brojni autori (primjerice Tomić, Botrić i Žilić, 2018.; Bedeniković, 2017.; Bruno, Marelli i Signerelli, 2014.; Bilić i Jukić, 2014.) prepoznaju mlade kao najveće gubitnike negativnih gospodarskih kretanja, pri čemu ekonomske krize osobito pogađaju upravo mlade, čime se njihov položaj u društvu i na tržištu rada prepoznaje kao veoma ranjiv. S obzirom na takvu situaciju, (socijalne) politike traže nove načine nošenja s tim socijalnim proble-

\footnotetext{
1 Termin je proširen tako da uključuje osobe u dobi od 15 do 24 godine, a kasnije i one u dobi od 15 do 29 godina, što je uglavnom prihvaćeno i kao referentni okvir politika u Hrvatskoj. (https://www. eurofound.europa.eu/hr/topic/neets)

2 Indikator: Young people neither in employment nor in education and training by sex, age and labour status (NEET rates), koji Eurostat vodi za dobnu skupinu 15 - 34 https://appsso.eurostat.ec.europa.eu/nui/ show.do?dataset=edat lfse 20\&lang=en
} 
mom i sprečavanja isključenosti mladih ljudi. Imajući u vidu takvu situaciju u našoj zemlji vezano uz NEET populaciju, u ovom radu sagledavamo glavne izazove NEET populacije i rada s njima na lokalnoj razini iz perspektive stručnjaka i mladih. ${ }^{3}$

U prvom dijelu rada predstavljene su karakteristike stručnog rada s populacijom mladih u Hrvatskoj te programi socijalne politike koji se bave tom populacijom. Nakon toga su prikazani metodologija provedenog kvalitativnog istraživanja sa stručnjacima i mladim pripadnicima NEET populacije te dobiveni rezultati. Slijedi diskusija, koja u fokus stavlja izazove rada s NEET populacijom u Hrvatskoj, te zaključak, u kojem su sumirani ključni argumenti vezani uz aktualne izazove u radu s NEET-om te prikaz preporuka za unaprjeđivanje prakse i istraživačkih studija u tom području.

\section{Stručni rad i programi socijalne politike usmjereni prema NEET populaciji u Hrvatskoj}

\subsection{Stručni rad s mladima s iskustvom ispadanja iz sustava obrazovanja $i$ NEET populacija}

Mladi koji su u riziku od ispadanja iz obrazovnog sustava predstavljaju specifičnu ranjivu skupinu jer je rizik od ispadanja iz obrazovnog sustava često povezan s mnogim drugim rizicima koji se javljaju tijekom njihovog odrastanja. Upravo se zbog tih rizika oni (a često i njihove obitelji) nalaze u nepovoljnom položaju te su izloženi društvenoj izolaciji. Dosadašnja istraživanja o ispadanju učenika iz obrazovnog sustava u Hrvatskoj pokazuju da u odnosu na neke druge europske zemlje Hrvatska nema zabilježene visoke postotke mladih koji ispadaju iz obrazovnog sustava (Matković, 2010.; Eurostat, 2013.; Eurostat, 2020.a). ${ }^{4}$

Prema podacima o mladima koji ispadaju iz obrazovnog sustava moglo bi se reći kako Hrvatska nema velik problem vezan uz NEET populaciju. No, bez obzira na niske stope ispadanja iz obrazovnog sustava, dosadašnja istraživanja i uvidi govore o ozbiljnosti posljedica za društvo koje se mogu javiti ako se problem ne sagleda dovoljno ozbiljno.

3 Rezultati istraživanja koji će biti predstavljeni dio su istraživanja provedenog u sklopu ESF projekta pod nazivom „Reaktivacija i integracija marginaliziranih mladih - NEET na tržište rada - RIM“, koji je provodio CERANEO - Centar za razvoj neprofitnih organizacija u partnerstvu s Gradom Zagrebom, Hrvatskim zavodom za zapošljavanje i Institutom za stručno usavršavanje mladih od svibnja 2018. do srpnja 2019. godine. Širi rezultati istraživanja i projekta mogu se naći u projektnoj publikaciji „Kako odgovoriti na izazove integracije i reaktivacije mladih u NEET statusu?“

${ }^{4}$ No u Hrvatskoj još uvijek nemamo ujednačen i sistematiziran način evidentiranja mladih koji ispadaju iz obrazovnog sustava. Poteškoće povezane s ujednačenim i sistematiziranim evidentiranjem podataka prije svega se odnose na redovitost prikupljanja podataka, način prikupljanja podataka i međusobnu suradnju relevantnih institucija (Baturina, Majdak i Berc, 2016.). 
Tako, na primjer, dosadašnja istraživanja o mladima koji ispadaju iz obrazovnog sustava govore da postoje značajne razlike u društvenom položaju mladih koji ispadaju iz obrazovnog sustava u odnosu na ostale mlade (Milas i Ferić, 2009.) te da niži stupanj obrazovanja roditelja i lošija financijska situacija obitelji pojačavaju rizik od napuštanja školovanja za mlade u tim obiteljima (Matković, 2010.). Nadalje, vrijedi dodati da su najčešći razlozi za ispadanje iz obrazovnog sustava povezani s problemima tijekom školovanja, nedovoljnom motivacijom za školu, problemima u ponašanju i lošim financijskim stanjem obitelji (Ferić, Milas i Rihtar, 2010.).

Istraživanje Berc, Bežovan i Majdak (2015.) istaknulo je nekoliko značajnih obilježja mladih koji imaju iskustvo ispadanja iz obrazovnog sustava. ${ }^{5}$ Pokazalo se da se radi najčešće o dječacima, da ti učenici najčešće imaju lošu sliku o sebi, da su češće depresivnog raspoloženja, nižeg samopouzdanja i samopoštovanja, zatim da imaju probleme u odnosima s vršnjacima u školi, probleme u ponašanju i neke poteškoće vezane uz školovanje te da se manje druže s vršnjacima u razredu. Identificiraju se i najvažniji razlozi za ispadanje vezani uz negativne ocjene, neopravdane izostanke i neprihvatljivo ponašanje u školi. Vezano uz sociodemografska i ekonomska obilježja obitelji mladih koji ispadaju iz obrazovnog sustava autori su dobili nalaze da se najčešće radi o jednoroditeljskim obiteljima, obiteljima u kojima su roditelji nižeg obrazovanja, prosječnog i/ili nižeg ekonomskog statusa, obiteljima u kojima postoje problemi ovisnosti, zlostavljanja, nezaposlenosti i/ili prezaposlenosti, obiteljima u kojima roditelji premalo sudjeluju u školovanju djece i ne prepoznaju njihove potrebe, sposobnosti i motiviranosti. Sva navedena obilježja mladih koji imaju iskustvo ispadanja iz sustava obrazovanja pokazuju da je tim mladima potrebno posvetiti posebnu pažnju u smislu osiguravanja sustava njihova praćenja nakon ranog napuštanja škole i osiguravanja programa za njihovo ponovno uključivanje u neke od oblika obrazovanja i osposobljavanja.

Isto tako, valja naglasiti da se neke intervencije i oblici stručnog rada s mladima koji su u riziku od ispadanja iz sustava obrazovanja provode unutar škole (pomoć u učenju, disciplinske mjere) te Centara za socijalnu skrb (mjere stručne pomoći i potpore u ostvarivanju skrbi o djeci te mjere intenzivne stručne pomoći i nadzora nad ostvarivanjem skrbi o djeci, Obiteljski zakon, 2015., čl. 134). ${ }^{6}$ Kod djece i mladih kod kojih se uoče neki od rizika (ili nekoliko njih istodobno) ${ }^{7}$ trebalo bi se sustavno usmjeriti upravo na njih te propisati stručne mjere koje bi bile upravo u svrhu prevencije ispadanja.

\footnotetext{
5 Istraživanje se, kao i ovo istraživanje, provodilo u geografskom kontekstu Grada Zagreba.

6 Međutim, navedene mjere nisu usmjerene isključivo na prevenciju ispadanja iz sustava obrazovanja jer se one ne poduzimaju zbog utvrđenog rizika od ispadanja, već se provode onda kada su evidentirani problemi u funkcioniranju i ponašanju kod djeteta i/ili problemi u obitelji koji utječu na djetetov razvoj, a na koje su država i društvo dužni reagirati.

${ }^{7}$ Za koje su dosadašnja istraživanja pokazala da su najvažniji rizici za ispadanje iz sustava obrazovanja.
} 
Kada je riječ o strukturi NEET populacije u Hrvatskoj, treba napomenuti da je među NEET stanovništvom u Hrvatskoj najprisutnije nezaposleno stanovništvo, odnosno ono koje želi raditi. Vezano uz praćenje NEET populacije u dobi od 20 do 34 godine podaci Eurostata za 2019. godinu pokazuju da je u Hrvatskoj ta populacija zastupljena sa $17 \%$, pri čemu je u toj dobnoj skupini udio žena u NEET položaju 20,7\%, a muškaraca 13,3\% (Eurostat, 2019.a). Gledajući specifičnije dobne podskupine, stopa NEET populacije u dobi od 20 do 24 godine iznosi 14,8\%, u dobi od 25 do 29 godina $18,8 \%$, a od 30 do 34 godine $17,2 \%$ (Eurostat, 2019.b). ${ }^{8}$

Udio neaktivnih te posebno onih koji ne žele raditi manji je od prosjeka EU-a. Vezano uz ukupnu nezaposlenost u Hrvatskoj, prema podacima Državnog zavoda za statistiku u 2018. godini neaktivnog stanovništva bilo je 1724 , a stopa nezaposlenosti iznosila je $8,4 \%$. Prema stupnju obrazovanja najviše je nezaposlenih sa završenom srednjom školom (46 089), a slijede oni sa završenom osnovnom školom (30 818). Najmanji je broj nezaposlenih u kategorijama sa završenim fakultetom, magisterijem ili doktoratom (13 650), zatim višom školom ili fakultetom prvog stupnja (10 145) i bez osnovne škole (9 611) (Državni zavod za statistiku, 2019.).

\subsection{Socijalne politike i uloga organizacija civilnog društva}

Nezaposlenošću mladih posljednjih se dvadesetak godina bave institucije Europske unije putem raznih strateških dokumenata i inicijativa. ${ }^{9}$ Ujedno, mladi su prepoznati $\mathrm{u}$ različitim aspektima socijalne politike i zapošljavanja kao skupina u riziku i oni na koje je potrebno usmjeriti projekte, programe i politike. ${ }^{10}$

Hrvatska je postojano jedna od zemalja s najvišim udjelom nezaposlenih mladih (15 - 24) u Europi, s najnepovoljnijim omjerom nezaposlenosti mladih i starijih, izrazito dugim trajanjem prelaska iz obrazovanja u tržište rada te visokim udjelom NEET populacije (Matković, 2019.). Među novim socijalnim rizicima u Hrvatskoj u recentnom periodu NEET populacija zauzima posebno mjesto (Bežovan, 2019.).

Mlade osobe karakterizira nedostatak radnog iskustva, pri čemu su posebno teže zapošljivi oni nižeg stupnja obrazovanja. Osim toga, mladi se često zapošljavaju na pre-

8 Podaci Eurostata za 2019. pokazuju da Italija ima 22,8\%, a Švedska 7,3\% udio NEET populacije u dobi 20 - 34 godine.

9 Najvažniji strateški dokument koji se bavi nezaposlenošću mladih u Europskoj uniji Europska je strategija zapošljavanja (ESZ) iz 1997. godine. ESZ je trenutno dio strategije Europa 2020. te se provodi kroz nadzorni mehanizam Europskog semestra. Provedbu ESZ-a podupire rad Odbora za zapošljavanje (EMCO), koji je glavni savjetodavni odbor u području zapošljavanja u Vijeću Europske unije za zapošljavanje i socijalna pitanja (EPSCO).

${ }^{10}$ Mladima se u Europskoj komisiji najviše bavi glavna uprava: Obrazovanje, mladi, sport i kultura. 
karnim radnim mjestima te se često nalaze u situacijama nezaposlenosti ili ekonomske neaktivnosti ${ }^{11}$ (Potočnik i Spajić-Vrkaš, 2017.), stoga su prepoznati kao posebno ranjiva skupina kojoj je potrebna podrška u zapošljavanju (Vlada RH, 2014.). Međutim, iskustvo pokazuje da im se ne pruža potrebno i odgovarajuće obrazovanje niti usmjeravanje kako bi se što bolje adaptirali na tržište rada i postali neovisni o drugim izvorima prihoda (Potočnik i sur., 2017.).

Neka istraživanja (poput Koller-Trbović, 2009.) pokazuju da mladi vide državu kao onu koja treba poduzeti više vezano uz problem nezaposlenosti mladih. Najsnažniji kanal socijalne politike predstavljaju aktivne politike zapošljavanja, međutim njihov je doseg neujednačen. Tako je u razdoblju 2011. - 2016. godine obuhvaćenost nezaposlenih mladih porasla sa $17 \%$ na $38 \%$, pri čemu su najveći doprinos dale mjere stručnog osposobljavanja (Matković, 2019.). Dionici evaluacije dionika stručnog osposobljavanja ističu da je sudjelovanje u tom programu bilo pozitivno iskustvo te da su tijekom osposobljavanja usvojili korisna i nova znanja, što je doprinijelo zapošljavanju na radnim mjestima s rutinskim ili jednostavnim poslovima izvan struke, unatoč nedovoljnim naknadama i manjku adekvatnih mentora (Bejaković i sur., 2016.). S druge strane, specifične marginalizirane skupine mladih imaju i specifična drugačija iskustva. Primjerice mladi koji su korisnici alternativnih oblika skrbi koriste mjeru javnih radova, no iskazuju određeni stupanj nezadovoljstva njome (Novosel, Preveden i Buković, 2015.) jer im ne pruža veću mogućnost daljnje integracije na tržište rada. No, ukupno gledajući, Hrvatska ima iznadprosječnu pokrivenost mjerama mladih u tzv. NEET statusu. Primjerice za 2016. godinu navodi se da je obuhvaćeno više od polovine (54\%) mladih osoba u dobi od 15 do 24 godine u NEET statusu (prosjek EU-a iznosi 42,5\%) (MRMS, 2019.b).

Kako bi se poboljšali izgledi NEET populacije u pogledu njihove integracije na tržište rada, Hrvatski zavod za zapošljavanje (HZZ) je najrelevantnija institucija. Od 2018. godine za svaku prijavljenu osobu provodi se statistički potpomognuto profiliranje kako bi se utvrdila „udaljenost“ osobe od tržišta rada te kako bi joj se mogle prilagoditi aktivacijske mjere ${ }^{12}$ (MRMS, 2019.a). Ujedno se jačaju kapaciteti Centara za informiranje i savjetovanje o karijeri (CISOK) ${ }^{13}$, koji obuhvaćaju i osobe koje nisu prijavljene u evidenciji HZZ-a. Oni su dijelom prepoznati i kao mjesta za aktivnosti dohvata NEET osoba, a osim toga razvijeni su i prilagođeni programi (primjeri-

\footnotetext{
11 Iako velik broj mladih još uvijek smatra kako je njihovoj dobnoj skupini lakše pronaći posao nego onima starijima (Buković, 2012.).

12 Tijekom 2017. godine započelo se s provedbom specifičnih aktivnosti za dugotrajno nezaposlene osobe, koje uključuju potpisivanje sporazuma o integraciji na tržište rada između HZZ-a i dugotrajno nezaposlene osobe.

13 96,6\% korisnika zadovoljno je ili vrlo zadovoljno uslugama Centra, dok $94 \%$ korisnika usluge procjenjuje korisnima ili vrlo korisnima (MRMS, 2019.a.).
} 
ce: e-usluge, kratke asistirane usluge i usluge individualnih savjetovanja) u skladu s posebnim potrebama ciljane skupine i lokalnim/regionalnim stanjem na tržištu rada (MRMS, 2019.b) ${ }^{14}$.

U Hrvatskoj se tek u posljednje vrijeme govori o programima rada usmjerenima na NEET populaciju, pa tako i na mlade ispale iz sustava obrazovanja, a koje uglavnom provode organizacije civilnog društva i Zavod za zapošljavanje. Najčešće se radi o programima kojima se mladi koji su ispali iz sustava obrazovanja osposobljavaju putem različitih radionica i seminara za mogućnost prijavljivanja za posao, stručnom osposobljavanju organiziranom od Zavoda za zapošljavanje za neko od traženih zanimanja, stjecanju nekih dodatnih znanja (učenje stranog jezika i sl.) ili pak povezivanju s poslodavcima i organizacijama radi potencijalnog zapošljavanja.

Grad Zagreb je, kao područje provođenja ovog istraživanja, u odnosu na druge aglomeracije natprosječno razvijena jedinica lokalne samouprave u Hrvatskoj te ima i posebno izdašno razvijenu socijalnu politiku, možemo ga smatrati lokalnom socijalnom državom (Babić i Baturina, 2019.). Grad Zagreb razvija i brojne usluge i programe za mlade, posebice one u nepovoljnom položaju (Grad Zagreb, 2014.; Babić i Baturina, 2019.). ${ }^{15}$ Osim toga značajni iznosi izdvajaju se za rad udruga mladih, koji su dijelom usmjereni na socioekonomsko uključivanje kako bi se prevenirao razvoj socijalnih rizika i nepovoljno djelovanje njihovih posljedica na kvalitetu života mladih (CERANEO, 2019.). Međutim, unatoč takvim nadprosječnim uvjetima vezano uz ponudu različitih programa i usluga za mlade koji traže posao u Gradu Zagrebu, istraživanje Savjeta mladih grada Zagreba (2016.) ukazuje na podatak da značajan broj nezaposlenih mladih ističe potrebu za dodatnim programima i daleko boljim mogućnostima informiranja u području zapošljavanja. Ističe se da je neinformiranost mladih vezana za zapošljavanje velik problem na području Grada Zagreba. Mladi naglašavaju olakšavanje postupka zapošljavanja (što se prema njihovim odgovorima najviše odnosi na osiguravanje pomoći pri zapošljavanju, usklađivanje obrazovanja s potrebama tržišta te poticaje za zapošljavanje mladih nakon završetka obrazovanja) kao jedan od najdjelotvornijih načina rješavanja svojih problema (Savjet mladih Grada Zagreba, 2016.).

Kako bi se produbile spoznaje o obilježjima NEET populacije i mogućnostima za pripremu za njihovo zapošljavanje te neke specifičnosti vezane uz zasnivanje radnog odnosa na području Grada Zagreba, cilj ovog istraživanja bio je ispitati iskustva struč-

14 Kovačić i Gvozdanović (2017.) izvan ovih institucija države smatraju važnim osnivanje višenamjenskih centara za mlade.

15 Primjer kojih mogu biti usluge zdravstvenog, psihoterapijskog i psihosocijalnog savjetovanja i informiranja, Centar za mlade grada Zagreba, različite usluge smještaja za djecu i mlade bez roditeljske skrbi ili pak Dnevni centar za rehabilitaciju djece i mladeži „Mali dom“. 
njaka u radu s mladim pripadnicima NEET populacije i iskustva mladih pripadnika NEET populacije sa stručnim radom koji se provodi s njima.

\section{Metodologija istraživanja}

\subsection{Sudionici istraživanja i način provedbe istraživanja}

Ovo kvalitativno istraživanje provedeno je s 25 nezaposlenih mladih pripadnika NEET populacije i s 15 stručnjaka koji imaju iskustvo stručnog rada s njima kako bi se iz više perspektiva dobili uvidi o obilježjima i životnim situacijama mladih uključenih u NEET populaciju u Zagrebu. Istraživanje je provedeno u periodu od 31. siječnja do 18. ožujka 2019 godine.

U uzorku stručnjaka sudjelovalo je petnaest stručnjaka, s kojima su provedeni polustrukturirani intervjui. ${ }^{16}$ Stručnjaci su odabrani po kriteriju zaposlenosti u ključnim institucijama koje rade s NEET populacijom (Centrima za socijalnu skrb i Hrvatskom zavodu za zapošljavanje) te po kriteriju geografske disperzije u urbanoj aglomeraciji Zagreb, koja je bila područje provođenja projekta. Polustrukturirani intervjui vodili su se prema pripremljenom predlošku, kojim se željelo obuhvatiti četiri tematske cjeline koje su se ustanovile pregledom relevantne literature i uvidima s fokusne grupe. U ovom će radu biti predstavljene dvije tematske cjeline ${ }^{17}: 1$. izazovi rada stručnjaka s NEET populacijom, 2. mogućnosti prevencije NEET statusa i integracija NEET populacije na tržište rada.

U uzorku NEET populacije sudjelovalo je 25-ero mladih koji su bili evidentirani pri Hrvatskom Zavodu za zapošljavanje ${ }^{18}$ i koji su sudjelovali na radionicama ENTREYOU modela, koji je provodio Hrvatski Zavod za zapošljavanje u suradnji s CERANEO-m. Ukupno je $s$ mladima provedeno pet fokusnih grupa. ${ }^{19} \mathrm{U}$ istraživanju je sudjelovalo 16 djevojaka i devet mladića. Prema obrazovnoj strukturi, desetero sudionika imalo je srednju školu kao završni stupanj obrazovanja, od toga jedan završenu gimnaziju, sedmero četverogodišnji i dvoje trogodišnji program strukovne srednje škole. Vezano uz visokoškolsku razinu obrazovanja, petero sudionika istraživanja imalo je

\footnotetext{
16 Prije provedbe intervjua jedanaest stručnjaka sudjelovao je u fokusnoj grupi s ciljem dobivanja okvirnog uvida u specifičnosti rada s NEET populacijom radi formuliranja relevantnih tema i pitanja za polustrukturirane intervjue.

17 Preostale dvije su bile: obilježja položaja NEET populacije/mladih u riziku da postanu NEET te NEET u kontekstu obrazovanja i tržišta rada.

18 Dio mladih nije bio prijavljen na HZZ, ali su se priključili jer su ih prijatelji informirali o aktivnostima koje su se provodile tijekom projekta Reaktivacija i integracija marginalnih mladih - NEET na tržište rada - RIM.

19 1. i 2. fokusnoj grupi u svakoj po pet sudionika, u 3. i 4. fokusnoj grupi u svakoj po šest sudionika i u 5 . fokusnoj grupi troje sudionika.
} 
diplomu prvostupnika, a deset sudionika diplomu magistra nakon završenog diplomskog programa studija. Vezano uz dobnu strukturu, sudionici istraživanja bili su u dobi od 19 do 29 godina. Fokusne grupe provedene su u prostorima Centra za mlade Zagreb. Od ukupno pet istraživačkih pitanja koja su razmatrana u širem istraživanju, u ovom radu bit će predstavljeni podaci za sljedeća dva: 1 . Kakva su iskustva mladih vezano uz suradnju s HZZ-om i dobivenom podrškom?, 2. Što mladi procjenjuju da je potrebno poboljšati u podizanju razine podrške za njihovo što ranije zapošljavanje?

\subsection{Obrada podataka}

U ovom istraživanju koristili smo višemetodski kvalitativni pristup, odnosno za prikupljanje podataka istovremeno smo koristili različite metode: intervjue za stručnjake i fokusne grupe za mlade, dok smo za obradu podataka dobivenih od stručnjaka koristili analizu okvira, a za podatke dobivene od mladih kvalitativnu analizu sadržaja, jer smo kod stručnjaka pristupili deduktivno, a kod mladih induktivno. Triangulacija podataka postignuta je na način da smo dobili i integrirali podatke ranijih istraživanja o ovoj tematici (Koller-Trbović, 2009.; Koller-Trbović, Žižak i Jeđud, 2009.; Ferić, Milas i Rihter, 2010.; .Berc, Bežovan, i Majdak, 2015.), koja su predstavljena u uvodnom tekstu, a zatim perspektivu stručnjaka i perspektivu mladih.

Budući da smo o perspektivi i mišljenjima stručnjaka u radu s mladim pripadnicima NEET populacije imali već neka saznanja iz ranijih istraživanja te da smo u fokusnoj grupi razlučili relevantne teme za daljnje istraživanje, sa stručnjacima smo odlučili provesti intervjue imajući u vidu da je ta skupina sudionika dostupnija (od NEET populacije) i da ih je lakše motivirati na sudjelovanje. Podaci dobiveni u razgovorima sa stručnjacima obrađeni su postupkom analize okvira (engl. framework analysis). Analiza okvira razvila se u kontekstu istraživanja javnih (socijalnih, zdravstvenih i sl.) primijenjenih politika s ciljem dobivanja specifičnih informacija koje će omogućiti određene uvide i preporuke u kraćem vremenskom razdoblju (Ritchie i Spencer, 1994.). Primarni je cilj deskripcija i interpretacija onog što se u vezi određenih socijalnih pitanja događa u specifičnom okruženju ${ }^{20}$, pa se stoga u ovom slučaju tematska analiza pokazala kao metoda izbora u obradi dobivenih podataka iz uzorka stručnjaka.

Kad se radi o mladim pripadnicima NEET populacije, trebalo je uzeti u obzir da se radi o teško dostupnom uzorku i da ih je zbog specifičnosti njihove situacije lakše motivirati na sudjelovanje u fokusnim grupama nego u intervjuima, pa su s njima provedene fokusne grupe, a podaci su obrađeni kvalitativnom analizom sadržaja. Kvalitativna analiza sadržaja metoda je kojom se nastoje prikazati u što izvornijem obliku

20 Ono što karakterizira analizu okvira unaprijed su definirana istraživačka pitanja na koja treba dati odgovor (a priori pitanja) u kratkom vremenskom roku te postojanje uzorka koji je namjerno odabran u kontekstu istraživačkih pitanja (Srivastava i Thomson, 2009.). 
specifičnosti komunikacijskog izražavanja sudionika istraživanja radi zadržavanja autentičnog konteksta i značenja prikupljenog sadržaja, stoga se ona pokazala metodom izbora za analizu tih podataka (Kondracki i Wellman, 2002., prema Hsieh i Shannon, 2005.).

Prikupljena građa u fokusnim grupama s mladima i intervjuima sa stručnjacima ${ }^{21}$ najprije je transkribirana, a zatim organizirana i analizirana. Inicijalni pojmovi koji su se pojavili u analizi empirije građe apstrahirani su u kategorije, koje će ovdje biti prikazane po tematskom okviru (za stručnjake) / istraživačkim pitanjima (za populaciju mladih). Dobiveni nalazi, odnosno pojedini pojmovi u prikazu rezultata ilustrirani su izjavama sudionika, koje su, kako bi se sačuvala anonimnost sudionika istraživanja, označeni šiframa koje su generalne prirode ${ }^{22}$. Teme, odnosno pojmovi i kategorije prikazane su u tablicama radi preglednosti prikaza dobivenih rezultata. Ilustrativne izjave u opisu rezultata navedene su u fusnotama.

Tijekom istraživanja bila su poštivana sva etička načela vezana uz provedbu kvalitativnih istraživanja u smislu anonimnosti i dobrovoljnosti kao i prava na izražavanje vlastitih mišljenja i prava na odustajanje.

\section{Rezultati istraživanja}

Rezultati istraživanja o percepciji nekih specifičnosti NEET populacije iz perspektive stručnjaka i pripadnika NEET populacije bit će prikazani prema zastupljenosti uzorka, pa će tako najprije biti prikazani podaci dobiveni od stručnjaka, a potom od mladih u NEET statusu.

\subsection{Izazovi u radu s NEET populacijom prema percepciji stručnjaka}

Podaci koji su dobiveni u razgovoru sa stručnjacima, koje ćemo prikazati prema temama određenima ciljevima istraživanja i prema tome oblikovanim predloškom intervjua, pokazuju kakva su njihova iskustva i izazovi u radu s NEET populacijom. Specifičnosti rada s mladima te specifičnosti samih institucija i nedostatak potrebne suradnje izdvojeni su kao najveći izazovi.

\footnotetext{
${ }^{21}$ Različit pristup u istraživanju oblikovao se prema samim karakteristikama ciljane populacije. Do mladih je NEET-ovaca izuzetno teško doći, kao i motivirati ih na razgovor, stoga su se fokusne grupe učinile primjerenijima kako bi se „prodrlo u njihova promišljanja“. S druge strane, sa stručnjacima se mogao napraviti dulji intervju o njihovom iskustvima i izazovima u radu s NEET populacijom.

22 Primjerice STR1 označava prvog intervjuiranog stručnjaka, STR2 drugog i tako dalje do STR15.
} 
Tablica 1.

Tema: Izazovi rada stručnjaka s NEET populacijom

\begin{tabular}{|l|l|}
\hline Kategorije & Pojmovi \\
\hline Ograničenja institucija & $\begin{array}{l}\text { Neadekvatnost prostornih uvjeta rada } \\
\text { Nedostatak vremena za (individualni) rad } \\
\text { Nedovoljno educiranje stručnjaka }\end{array}$ \\
\hline Pristupi u radu s NEET populacijom & $\begin{array}{l}\text { Rad na motivaciji } \\
\text { Pristupi i oblici rada s mladima } \\
\text { Uključivanje u obrazovne i programe za uključivanje na tržište rada }\end{array}$ \\
\hline $\begin{array}{l}\text { Suradnja s drugim institucijama i } \\
\text { dionicima }\end{array}$ & $\begin{array}{l}\text { Protočnost i usklađenost informacija } \\
\text { Rad s drugim dionicima i institucijama }\end{array}$ \\
\hline
\end{tabular}

Unutar teme „Izazovi rada stručnjaka s NEET populacijom“ stručnjaci naglašavaju brojna ograničenja unutar samih institucija u kojima rade. Neki navode neadekvatne uvjete u pogledu nedostatka prostora za rad ili dijeljenja prostora s drugim kolegama dok razgovaraju s pripadnicima NEET populacije o njihovim osobnim i osjetljivim temama i problemima. Velik problem koji stručnjaci posebno naglašavaju nedostatak je vremena za stručni rad s mladima. Opterećenost normama i velikim brojem korisnika onemogućava im dostatno i procesno posvećivanje individualnom radu s mladim NEET-ovcima, čak i kada jasno uočavaju potrebu. ${ }^{23}$ Osim toga, stručnjaci naglašavaju da su im za učinkovitiji rad s mladima potrebne i dodatne edukacije, koje su im rijetko omogućene. $^{24}$

U samom radu s NEET populacijom stručnjaci ističu izazove u prenošenju informacija mladima i njihovoj recepciji. Pri tome su posebno naglašene poteškoće u motiviranju i aktiviranju, iako stručnjaci naglašavaju da senzibilitet i podrška kolega iz

23 STR4, „[...] postali papirnati socijalni radnici, ne. Jer mi radimo samo to, mi ne možemo raditi nikakvo savjetovanje, usmjeravanje, uh, nemamo, imamo neki zakonski okvir za to, al' ne'amo u praktičnom smislu vrijeme, a nemamo zapravo niti alate jer taj dio sustava zanemaruje socijalni rad."

STR9 „[...] i ne možemo raditi na način da ja uz fluktuaciju neku, od sto ljudi, recimo, koji ulaze i izlaze, da ja radim s 400, uvijek imam otprilike 400 ljudi, ja ne mogu raditi individualno u smislu da ih svaki mjesec... s nekim razgovaram, osim kad si ja odaberem uvijek neke za koje vidim da imaju problema."

24 STR5 „Pa sigurno da da, naše... Mi imamo jako puno nekakvih ovlasti i zadataka i sigurno da se... Da u nečemu plivamo i da se ne snalazimo dobro. Svaka neka edukacija ili nešto u čemu bi nas se moglo usmjerit ili nama pružit da mi možemo drugima pružit bi bila dobrodošla.“ 
različitih institucija prema mladima postoji ${ }^{25}$. Stručnjaci naglašavaju aspekte različitih pristupa i oblika rada koje pokušavaju primijeniti u radu s mladima kako bi pozitivno utjecali na njihovu socijalnu ili radnu integraciju. ${ }^{26}$ Dio rada stručnjaka sastoji se u osvještavanju mladih o opcijama koje im stoje na raspolaganju za poboljšanje vlastitog položaja u društvu, obrazovanju i tržištu rada. ${ }^{27}$

Suradnja s drugim institucijama je izazov. Stručnjaci navode da je koordinacija rada $s$ drugim institucijama i dionicima manjkava. Ističu dobre odnose sa školama ili udrugama, no jasno je da nedostaje sustavnost rada. ${ }^{28}$ Informacije često nisu protočne ili stručnjaci ne dolaze do relevantnih informacija o tome što druge institucije i dionici rade, a to bi im moglo pomoći u radu s NEET populacijom. ${ }^{29}$ To dovodi do nedovoljne suradnje s resursima i institucijama manjeg usmjeravanja koji rade s mladima.

U sljedećoj temi željelo se identificirati što od resursa usmjerenih na NEET populaciju postoji u praksi, što stručnjaci vide kao dobru praksu i što nedostaje.

\subsection{Prevencija ulaska mladih u NEET status prema percepciji stručnjaka}

U nastavku slijede podaci koji pokazuju kako stručnjaci koji rade s NEET populacijom temeljem svog iskustva procjenjuju mogućnost prevencije ulaska mladih u NEET status i njihovu integraciju na tržište rada.

25 STR6 „[...] da svaku instituciju koju sam nazvala i gdje sam se s kolegama čula, da tu postoji ta nekakva i dalje borba za njih, ono da im... Da im se, ne znam, ako ne... Ne progleda kroz prste, da ih se pogura, pa ajmo nešto napravit, to je takav moj dojam koji sam doživjela od onih ljudi s kojima ja komuniciram." 26 STR3 „Njemu trebate ponudit ono što njemu treba. On treba biti uspješan, to je osnov svega. Ako je dijete neuspješno u jednom segmentu, u drugome, bit će i u trećem, al ako ga potičete i motivirate da bude, on će se naći negdje i on će biti negdje uspješan".

27 STR12 ,[...] dakle, to su, to su programi koji su namijenjeni svima, naravno da ćemo posebno poticat NEET-ovce, odnosno osobe koje su općenito duže u evidenciji, možda ne čak i duže od godine dana, ali kad imate osobu koja je jako dugo u evidenciji, a vidi se da je zdrava, da može radit, zašto ne bi išla na obrazovanje pa stekla još nešto i to ima isto jako lijepih priča, osoba koje završe neko obrazovanje preko nas se zaposle u toj branši, bez obzira što je ona po struci“.

28 STR2 „Ono što je kod nas u Centrima problem, mi često nemamo priliku da nas više koji radimo na tim poslovima ide na neku edukaciju, nego ide jedan, nekad nijedan jer, je li, taj dan mora bit na sudu i provest će cijeli dan, ili ne znam što, ali mi se čini da, da fali to nešto da imamo, imamo neku sredinu koja će koordinirat te aktivnosti, znači postoje službe koje... Koje rade s tim mladim ljudima, koje imaju podatke o njima, koje imaju obavezu i priliku uputiti ih negdje da im se na neki način omogući to nešto što njima treba, a ovako kad imamo puno tih udruga, mi često za neku i ne znamo ili znamo, ali ne znamo što oni rade, kolko dobro to nešto rade“.

29 Da, nije sustavno, jel, da vi sad, ne znam, evo, recimo ja, kad mi dođe neki momak i hoću nešto $s$ njim napravit, da ja sad imam neku mrežu [...] Tako je. Nema, nego sad ko, zavisi od mog telefoniranja.“ 
Tablica 2.

Tema: Mogućnosti prevencije i integracija osoba u NEET statusu

\begin{tabular}{|l|l|}
\hline Kategorije & Pojmovi \\
\hline $\begin{array}{l}\text { Učinkoviti programi rada s NEET } \\
\text { populacijom }\end{array}$ & $\begin{array}{l}\text { Preventivni programi } \\
\text { Dodatne i fleksibilne edukacije } \\
\text { Priprema za tržište rada }\end{array}$ \\
\hline Primjeri dobre prakse & $\begin{array}{l}\text { Aktivne politike tržišta rada } \\
\text { Suradnja s udrugama }\end{array}$ \\
\hline Mogućnosti i ograničenja institucija & $\begin{array}{l}\text { Kontinuiranost programa } \\
\text { Priontivnost i ustroj rada institucija }\end{array}$ \\
\hline
\end{tabular}

Unutar teme „Mogućnosti prevencije i integracija osoba u NEET statusu“ stručnjaci naglašavaju preventivne programe kao nužnost. Vide trenutni nedostatak i potrebu za započinjanjem prevencije u ranoj dobi. ${ }^{30} \mathrm{~S}$ druge strane, stručnjaci iskazuju potrebu za specifičnijim edukacijama u kojima bi mladi jasno prepoznali doprinos vlastitom zapošljavanju. One, prema stručnjacima, moraju biti fleksibilne, uvažavajući da mnogi mladi NEET-ovci imaju ili su imali značajnih poteškoća u srednjoškolskom obrazovanju ili se teško uklapaju u tradicionalne forme obrazovanja. ${ }^{31}$ Pri tome stručnjaci upozoravaju na važnost specifičnih priprema za tržište rada, koje bi trebale početi još za vrijeme formalnog obrazovnog procesa. $^{32}$

Stručnjaci vide mogućnosti iskorištavanja ili poboljšanja već postojećih programa. Mješovitih su dojmova o mjerama aktivne politike tržišta rada, u kojima prepoznaju određene mane, ali s druge strane navode da su bile „spas“ za određene NEET-ov-

30 STR6 "Negdje tu bi išlo, u školi bi išlo na neku već, na neku prevenciju s nekim, ne znam, radionicama i osvijestit nekako, empatizirat ne samo ti kao stručnjak prema toj osobi mladoj, nego i školu, razred jer najčešće se oni osjećaju uvijek kao, kako ono, kak se kaže, kao crne ovce. Kao da ni sami ne osjećaju da ne pripadaju“.

31 STR1 „[D]ostupno je jako puno i online edukacija, došli su kanali koji su njima pristupačniji za edukaciju, brži kanali, niko više od mladih, ja sad kad znam nekakve programe obrazovanja koji traju po godinu, dvije dana, teško, teško da će netko bit tolko dosljedan, ne zato što neće, nego zbog životnih okolnosti, od promjene stanovanja, posla, života, mislim da su ove brže edukacije, ciljane edukacije, specifične, njima puno prihvatljivije."

32 STR1 „Ne radit s njima, recimo, taj dio prevencije puno bitniji po meni, već to profesionalno usmjeravanje kroz osnovnu školu pojačat, prije, da ono počne prije završnih razreda, osmog razreda, a pogotovo u srednjoj, znači, ove gimnazijalce, ako i misle u strukovnu, već u srednju nekako selektirat, u tom dijelu da znaju šta ih... Koje su im uopće opcije sve moguće i kako je koja, koliko je koja opcija prohodna jer njima se često daju informacije do određene točke." 
ce. ${ }^{33}$ Mjere poput SOR-a i pripravništva stručnjaci drže korisnima kao put prema zaposlenju, iako iskazuju i mane. Naglašavaju veću potrebu za koordinacijom do sada postojećih razmrvljenih javnih programa i djelovanja organizacija civilnog društva. Stručnjaci su tek ponegdje upoznati s programima udruga. ${ }^{34}$

Institucije u kojima stručnjaci rade ne pokazuju veću proaktivnost u razvijanju novih programa. Pri tome se jasno uočava da je ustroj i način rada institucija ograničenje za integraciju NEET populacije. ${ }^{35}$ Općenito postoji dojam stručnjaka o nedostatnoj povezanosti svih aktera kao i manjku protočnosti informacija i komunikacije ${ }^{36}$. Stručnjaci iskazuju i probleme manjka kontinuiteta programa na koje bi mogli usmjeriti mlade. Isto tako stručnjaci, kao oni koji rade $s$ populacijom mladih, vide da mladi, a posebice NEET populacija, nisu prioritet ni politici ni u društvu, što ograničava razvoj usmjerenih programa i politika. ${ }^{37}$

\subsection{Iskustva suradnje NEET populacije s Hrvatskim Zavodom za zapošljavanje}

U nastavku će biti prikazani rezultati vezani uz percepciju mladih nezaposlenih osoba o iskustvima suradnje s djelatnicima Hrvatskog zavoda za zapošljavanje i dobivenoj podršci u svrhu nalaženja zaposlenja. Analizom odgovora sudionika istraživanja dobiveno je deset kategorija s pripadajućim pojmovima i izjavama.

33 STR10 „Da, prvo zapošljavanje, da. Tu mi participiramo pola-pola. Stručno je bilo dobro, a u jednu ruku nije bilo dobro jer su poslodavci to jako iskorištavali. To sam saznala kroz stranke. Tu su mi znali reći, ovaj, ne smiješ to prekinut, moraš vratit novce, to uopće nije lijepa stvar“.

34 STR3 „Ovi rade recimo dobre možda te neke male grupice preventivne, ovi rade, recimo, Modus, on ima krasne te programe grupne za djecu, ne znam, za djecu rastavljenih roditelja imaju onaj Pinklec, onda imaju, ne znam... Ima još tih individualnih, onako, periodičnih, em, recimo, meni je tu Tesa na trgu, oni isto mi imaju taj rad sa djecom kroz grupne, kroz individualne... Svi ti u biti, bilo kakav rad sa djecom radi nekakav rezultat".

35 STR15 „[M]islim da bi trebalo malo više poraditi na tim... intervencijama u smislu pred kraj obrazovanja, završni razredi, da tu možda nekak bude i više da predstavnici Zavoda, i ono što smo bili rekli možda i Centra za socijalnu skrb i tako, da se njima dođe da se prezentira, isto i da budu uključeni i poslodavci, i da to bude ono nešto što je na državnoj razini, a ne ovak."

36 STR2 „I ti neki projekti koji krenu, to je isto nešto vezano za novac, netko kaže okej možete nam slati jer smo sad u tom i onda to traje jedno vrijeme i iza toga je stopirano jer nema novca... [...] tako je, nemate više mogućnost svoje korisnike upućivat u takve programe, tako da mi se čini da bi to nešto trebalo biti, i to bi možda pomoglo i za našu međusobnu komunikaciju, razmjenu informacija. Ja recimo moram priznat, ne zato što nisam dovoljno zainteresirana, ali ne stignem od ovog našeg, je li, posla, od našeg svaštarenja jer moramo bit..."

37 STR12 „Pa državi je deklarativno, svakoj državi je prioritet, ovaj, održavati supstancu, dakle mlade. Nema države koja neće reć i koja neće pokušat riješit taj problem. [...] Heh, kad kažete prostora, to znači novaca, znate, kad kažete prostora to znači novaca, a sad kad vidite dobnu strukturu onih koji odlaze i kad vidite demografsku sliku, onda je odgovor jasan." 
Tablica 3.

Istraživačko pitanje: Iskustva suradnje s HZZ-om NEET populacije i dobivena podrška

\begin{tabular}{|c|c|}
\hline Kategorije & Pojmovi \\
\hline $\begin{array}{l}\text { Rutinski poslovi evideniranja i } \\
\text { nekorisno informiranje }\end{array}$ & $\begin{array}{l}\text { Evidencija dolazaka i statistika } \\
\text { Nekoristan rutinski pregled natječaja } \\
\text { Nekorisne konzultacije } \\
\text { Nekorisna preporuka posla }\end{array}$ \\
\hline $\begin{array}{l}\text { Nekompetentnost djelatnika HZZ-a } \\
\text { za rad s nezaposlenim osobama }\end{array}$ & $\begin{array}{l}\text { Nedovoljno znanje i nedostatak informacija o ponudama posla } \\
\text { Nepoznavanje tržišta rada u državnom i privatnom sektoru } \\
\text { Nedostatak primjera iz prakse u vidu savjeta o izradi financijskog plana } \\
\text { Nekompatibilne ponude poslova u odnosu na kvalifikaciju } \\
\text { Omalovažavanje prvostupnika }\end{array}$ \\
\hline Zastarjela kompjuterizacija HZZ-a & $\begin{array}{l}\text { Zastarjelo vođenje administracije } \\
\text { Potreba za unaprjeđenjem kompjuterizacije HZZ-a }\end{array}$ \\
\hline Izostanak ažurnosti savjetnika & $\begin{array}{l}\text { Dugo čekanje odgovora i informiranja } \\
\text { Potpuni izostanak korespondencije putem e-maila } \\
\text { Rijetko obavještavanje o ponudi za posao }\end{array}$ \\
\hline $\begin{array}{l}\text { Nedostatak sigurne podrške i } \\
\text { učinkovitosti HZZ-a }\end{array}$ & $\begin{array}{l}\text { Izostanak savjeta i oslonca } \\
\text { Izostanak sigurnosti od države }\end{array}$ \\
\hline $\begin{array}{l}\text { Izostanak konkretne pomoći od } \\
\text { savjetnika }\end{array}$ & $\begin{array}{l}\text { Izostanak tehničke podrške } \\
\text { Izostanak posebne pomoći od savjetnika } \\
\text { Nezainteresiranost savjetnika }\end{array}$ \\
\hline Neujednačeno informiranje & $\begin{array}{l}\text { Nejednako proslijeđivanje informacija } \\
\text { Neujednačeno pomaganje } \\
\text { Nedostatak pomoći zbog čestih izmjena savjetnika }\end{array}$ \\
\hline Angažirani i posvećeni savjetnici & $\begin{array}{l}\text { Informiranje o aktualnim ponudama } \\
\text { Motivirajući savjetnici }\end{array}$ \\
\hline Pružanje psihološke podrške HZZ-a & $\begin{array}{l}\text { Izvor pružanja psihološke podrške } \\
\text { Dobivanje psihološke pomoći }\end{array}$ \\
\hline
\end{tabular}

Nezaposleni mladi koji su prijavljeni na Zavodu za zapošljavanje smatraju da Zavod najčešće radi poslove koji su rutinski poslovi evidentiranja i nekorisnog informiranja jer se jedino vodi evidencija dolazaka i statistika ${ }^{38}$ te imaju iskustvo da je savjetnik

38 „Samo generički, javim se njoj što sam ja poslala.“ „U redu, zabilježeno. Iduće Vam je javljanje taj i taj datum." (S23); "[...] Uglavnom se to sve svodi na papirologiju, odnosno svojevrsna statistika od straneHZZ-a.” (S17). 
izvršio nekoristan rutinski pregled natječaja ${ }^{39}$ ili da su dobili nekorisne konzultacije. ${ }^{40}$ Neki sudionici kazuju da su od savjetnika dobili informaciju koja je bila nekorisna preporuka posla ${ }^{41}$, a ocjenjuju i da su neki savjetnici HZZ-a nekompetentni u radu $s$ nezaposlenim osobama, da pokazuju nedovoljno znanje i nedostatak informacija o ponudama posla. ${ }^{42}$ Osim toga, nepoznavanje tržišta rada u državnom i privatnom sektoru također je nešto na što su nezaposleni mladi stavili naglasak kad je u pitanju suradnja sa savjetnicima HZZ-a. ${ }^{43}$

Sudionici istraživanja u suradnji s HZZ-om također uočavaju nedostatak primjera iz prakse u vidu savjeta o izradi financijskog plana. ${ }^{44}$ Također, moglo se uočiti da nezaposleni mladi smatraju da su od savjetnika dobili nekompatibilne ponude poslova u odnosu na kvalifikaciju ${ }^{45}$ te da su imali iskustvo omalovažavanja prvostupnika od savjetnika. ${ }^{46}$

Vezano uz neka tehnička obilježja suradnje s HZZ-om, mladi uočavaju zastarjelu kompjuterizaciju HZZ-a, što iskazuju kroz iskustvo korištenja zastarjelog vođenja administracije od savjetnika te ističu potrebu za unaprjeđenjem kompjuterizacije HZZa. ${ }^{47}$ Nastavno na te tehničke nedostatke HZZ-a nadovezuje se izostanak ažurnosti

39 Što potvrđuje primjer sljedeće izjave „Počela gledati i skrolati po natječajima. Pa to i ja radim! NE treba mi to. Nekako, dosta robotski mi je to djelovalo" (S22).

40 Što potvrđuje sljedeća izjava: „Primjerice na konzultacije, dosta prolazimo kroz moj životopis i jednostavno me savjetnica ispituje preko njihovog portala dal bi htio radit ovo, dal bi htio radit ono. To zapravo mogu sam od sebe, sa svog laptopa odabrat" (S17).

41 Što se vidi u sljedećoj izjavi "[...] oni šalju bezveze poslove“ (S7).

42 O čemu govori sljedeća izjava sudionika istraživanja „Ali kad sam pitao one osnovne informacije, npr. kako bih ja stekao to iskustvo da izađem iz tog začaranog kruga? Nisu mi imali pojma. One osnovne informacije mi nisu mogli odgovoriti u vezi mog, tog obrazovanja." (S25).

43 Što se može vidjeti u sljedećoj izjavi: "Oni moraju biti kompetentni, oni moraju savršeno poznavati tržište rada, pogotovo zato što su opredijeljeni za određene struke. Dakle, moja savjetnica upravo je za humanističke znanosti i mislim da je za nastavnike, profesore. I oni ne poznaju tržište rada. Oni trebaju znati ne samo državne institucije, nego i privatne firme i uputit nas." (S21).

44 Što potkrepljuje sljedeća izjava: „Nisam dobila nikakve informacije u smislu na mom nekakvom primjeru što bih ja tu napravila, kako bih izradila financijski plan i sve to skupa jer to je sve komplicirano." (S21).

45 Što potvrđuje primjer sljedeće izjave „[...] opet dobivam nekakve oglase koji jednostavno nisu u mojoj struci kao na primjer spasioc" (S15).

46 Što pokazuje sljedeća izjava mlade nezaposlene osobe „[...] u jednom trenutku nas se omalovažava zato što smo mi sad prvostupnici trenutno." (S8).

47, „...] a pa ovo bi htjela da burza bude, da bude unaprjeđenija.“ (S16). „[...] imaju jako zastarjelo administracijsko... To na kompjuterima. Kažu da od 2010. to još vrijedi, da je to jako sporo. Da malo unaprijede administraciju, da to brže nekako ide." (S25). 
savjetnika, koji se očituje kroz dugo čekanje odgovora i informiranja ${ }^{48}$,a ponekad i potpuni izostanak korespondencije putem e-maila. ${ }^{49}$

Mladi nezaposleni također kroz iskustvo suradnje s HZZ-om uočavaju nedostatak sigurne podrške i učinkovitosti HZZ-a, pri čemu naglašavaju izostanak oslonca te izostanak dobivanja sigurnosti od države. ${ }^{50}$

Sljedeća kategorija koja opisuje specifičnosti suradnje NEET populacije s HZZ-om tijekom traženja posla i njihove nezaposlenosti izostanak je konkretne pomoći od savjetnika HZZ-a. Sudionici istraživanja u tom kontekstu uočavaju izostanak tehničke podrške $e^{51}$, zatim izostanak posebne pomoći od savjetnika ${ }^{52}$ te nezainteresiranost savjetnika. ${ }^{53} \mathrm{U}$ slijedu nepovoljnih iskustava nezaposlenih mladih definirana je kategorija neujednačenog informiranja, koje se očituje kroz nejednako prosljeđivanje informacija ${ }^{54}$ te kroz neujednačeno pomaganje $\mathrm{e}^{55}$. Osim toga, česte izmjene savjetnika također doprinose nedovoljnoj efikasnosti službi HZZ-a. ${ }^{56}$

No, mladi su isticali (u nešto manjoj mjeri) i pozitivna iskustva s uslugama HZZ-a. Jedna od kategorija odnosi se na angažirane i posvećene savjetnike HZZ-a pri, čemu mladi ističu da su ih informirali o aktualnim ponudama ${ }^{57}$ i da su bili motivirajući ${ }^{58}$

48 O čemu svjedoči i sljedeća izjava „Znači od 11. mjeseca što je gospođa u mirovini, njima je tri mjeseca trebalo da mene obavijeste." (S23).

49 „[...] savjetnik nijednom nije neš odgovorio, niti na jedan mail.“ (S14). Rijetko obavještavanje o ponudi za posao u nekoliko mjeseci: „[...] I to je to, to je jedini mail koji sam u tri mjeseca dobila...“ (S13).

50 „Mislim da se ne mogu baš na nekog osloniti“ (S13). „Meni je nekako uopće ono da nema nekakve potpore te, kak' sam rekla, nekakve državne ne potpore, da je nekakve sigurnosti u tom smislu." (S16).

51 „Tu tehnički nisam imala nikakvu podršku niti pomoći“ (S2).

52 „Ali što se tiče generalno rada moje savjetnice, mislim da nije ništa posebno previše napravila za mene." (S21).

53 „[...] a ova se na primjer uopće ne trudi.“ (S8); „Nekako kao da im se ne da raditi...“ (S7).

54 „Znači kolegica je završila isto što i ja, imamo istu savjetnicu, ja sam dobila za to, ona nije dobila.“ (S23).

55 „Ja mislim da dosta burza pomaže. Mislim ne baš svim ljudima, al nekima...“ (S3).

56 Što potvrđuje sljedeća izjava sudionika istraživanja: „Ja sam na burzi od 6. mjeseca i dobila sam već treću savjetnicu. To se oni valjda reorganiziraju unutar sebe. Od 6. mjeseca tri savjetnice - i da mi želi pomoći ne može." (S23).

57 „[...] na razgovoru prije mjesec dana gospođa mi je baš objašnjavala koje mi sve beneficije nude i na koncu me preporučila za ovaj intervju." (S20).

58 „Znači srela sam se sa jako dragom ženom, puno mi je pomogla i oko sezone i slala je evo i predložila mi je puno toga. Tako da ja evo imam iskustva s dobrom savjetnicom“ (S11). 
te ažurni i korisni savjetnici ${ }^{59}$. Važan dio iskustva nezaposlenih mladih sa savjetnicima HZZ-a informiranje je o dodatnim edukacijama, što je vidljivo iz sljedećih pojmova i izjava: informiranje o edukativnim modulima za nezaposlene ${ }^{60}$, informiranje o mogućnosti prijave na osposobljavanje za pisanje EU projekata ${ }^{61}$, često slanje ponuda za posao i intervjue ${ }^{62}$ i ponude besplatnih radionica ${ }^{63}$. Prikaz percepcije suradnje mladih nezaposlenih osoba s HZZ-om završava kategorijom koja pokazuje prepoznavanje važnosti osobne podrške osobama koje traže posao, tj. pružanje psihološke podrške od HZZ-a, što je vidljivo kroz imenovanje izvora pružanja psihološke podrške ${ }^{64}$ te značenja dobivanja psihološke pomoći ${ }^{65}$, što se prepoznaje kao vrijedan iskorak u pružanju podrške nezaposlenim osobama koje se obraćaju za pomoć HZZ-u.

\subsection{Prijedlozi NEET populacije o mogućnostima unaprjeđenja rada i podrške HZZ-a nezaposlenim mladima}

$\mathrm{Na}$ istraživačko pitanje „Što mladi procjenjuju da je potrebno poboljšati u podizanju razine podrške za njihovo što ranije zapošljavanje?" temeljem analize podataka dobiveno je pet kategorija i pripadajućih pojmova.

59 „[... ja isto imam dobru, imamo istu savjetnicu na burzi, tako da, stvarno je ažurna i edukaciju mi je poslala. Tako da, ne mogu reći, stvarno pomaže“ (S12).

60 „[...] mislim savjetnica je rekla za ovu, ove nekakve module i vjerujem da mi to može pomoć s te strane." (S 15).

61 „Tako da sam ja unutar tog projekta, osposobljavanje za pisanje EU projekata. I to je nešto što je moja savjetnica meni poslala link jer inače nema šanse da bih došla sama do njega" (S21).

62 „[...] da šalje ponude za poslove, ova mi gospođa šalje izuzetno često. Uvijek mi nudi: „Tu otiđite na tečaj za ovo i ovo..." Jako dobra osoba." (S20).

63 „[...] na burzi ima dosta sad ovih, tih radionica i edukacija što su besplatne ili ono se plaćaju, ali dobiješ novce da platiš." (S14).

${ }^{64}$ Mislim možda naš mentor na zavodu za zapošljavanje. On bi nas možda saslušao." (S3).

65 „Što se tiče psihološke te pomoći, to je zasigurno na primjer jedna dobra ideja što je HZZ napravio.“ (S5). 
Tablica 4.

Istraživačko pitanje: Percepcija mladih nezaposlenih o potrebnim poboljšanjima u podizanju razine podrške za njihovo što ranije zapošljavanje

\begin{tabular}{|c|c|}
\hline Kategorije & Pojmovi \\
\hline $\begin{array}{l}\text { Smanjenje korupcije i nepoštenog } \\
\text { zapošljavanja }\end{array}$ & $\begin{array}{l}\text { Smanjivanje nepotizma i „veza“ pri zapošljavanju } \\
\text { Smanjivanje zapošljavanja s lažnim diplomama }\end{array}$ \\
\hline $\begin{array}{l}\text { Povećanje brige za mentalno zdravlje } \\
\text { mladih nezaposlenih }\end{array}$ & $\begin{array}{l}\text { Povećati emocionalnu podršku za mlade } \\
\text { Pomoć pri podizanju samopouzdanja }\end{array}$ \\
\hline $\begin{array}{l}\text { Uvođenje dodatnih poticajnih mjera za } \\
\text { rano zapošljavanje mladih }\end{array}$ & $\begin{array}{l}\text { Uvođenje mentora za osobe bez radnog iskustva } \\
\text { Uvođenje obaveznog stažiranja } \\
\text { Manja davanja poslodavaca za zaposlenike } \\
\text { Sustavni sufinancirani tečajevi za nezaposlene } \\
\text { Smanjenje papirologije } \\
\text { Novčana pomoć }\end{array}$ \\
\hline Praćenje potreba na tržištu rada & $\begin{array}{l}\text { Smanjiti dobnu neuravnoteženost na tržištu rada } \\
\text { Veća kontrola terenske prakse }\end{array}$ \\
\hline $\begin{array}{l}\text { Mijenjanje dijelova programa } \\
\text { obrazovnog sustava }\end{array}$ & $\begin{array}{l}\text { Veća kontrola terenske prakse } \\
\text { Više terenske prakse u školama } \\
\text { Uvođenje više sadržaja u škole za pripremu za tržište rada } \\
\text { Promjena programa u školama } \\
\text { Uvođenje potpuno besplatnog obrazovanja } \\
\text { Pomoć pri odabiru zanimanja }\end{array}$ \\
\hline
\end{tabular}

Sudionici istraživanja izjavili su da su tijekom javljanja na natječaje za zapošljavanje uočili određene netransparentnosti i neke druge nepravilnosti kod odabira kandidata za pojedino radno mjesto, te stoga ističu da je smanjenje korupcije i nepoštenog zapošljavanja jedna od potrebnih promjena koje bi se trebale dogoditi kako bi se svima omogućilo korektno natjecanje za dobivanje posla. Tome u prilog govore dobiveni pojmovi i pripadajuće izjave sudionika istraživanja, kao što su smanjivanje nepotizma i „veza“ pri zapošljavanju ${ }^{66}$ te smanjivanje zapošljavanja s lažnim diplomama ${ }^{67}$.

Kako bi se mladim nezaposlenim osobama pomoglo u suočavanju s težinom iskustva nezaposlenosti, sudionici istraživanja ističu da bi bilo potrebno povećati brigu za njihovo mentalno zdravlje te u tom smislu navode da bi bilo značajno povećati

66 „Pa ovi neki poslodavci koji stave oglase samo reda radi, a onda mislim nije tajna da zaposle nekog svog preko veze.“ (S1). „Moj zaključak svih ovih naših priča je da ništa bez veze. Ako nemaš veze, teško. Danas, koliko ja znam, ljudi koji imaju veze uspijevaju i bez faksa, sa srednjom školom, čak i bez srednje škole, zaposle se“ (S24).

67 „Znači mi koji i hodamo na predavanja i ispite smo polagali i sve. Da mi ne možemo dobit posao, a neko kupi neku diplomu za tjedan dana ju dobije ili ima neku vezu, uopće nije kvalificiran za to i radi posao, a mi koji tražimo posao i sve koji imamo neka znanja koja bi mogli pokazati i sve samo da dobijemo priliku nama je to onemogućeno." (S8). 
emocionalnu podršku za nezaposlene mlade ${ }^{68}$ te pružiti pomoć pri podizanju samopouzdanja ${ }^{69}$.

Kako bi se na sustavnoj razini podigla kvaliteta podrške za zapošljavanje mladih osoba, sudionici istraživanja predlažu uvođenje dodatnih poticajnih mjera za rano zapošljavanje mladih na način da se uvedu mentori za osobe bez radnog iskustva ${ }^{70}$, zatim obavezno stažiranje $\mathrm{e}^{71}$, sustavni sufinancirani tečajevi za nezaposlene ${ }^{72}$ i novčana pomoć za nezaposlene ${ }^{73}$.

Osim toga, sudionici istraživanja uočavaju da bi i poslodavcima trebalo pomoći u zapošljavanju nove radne snage i ponuditi im olakšice kao što su manja davanja za zaposlenike. ${ }^{74}$ Konačno, ono što mlade nezaposlene kroz iskustvo traženja posla prati, opsežna je administracija, te stoga predlažu smanjenje papirologije. ${ }^{75}$ Osim navedenih prijedloga za neke sustavne promjene vezane uz podršku pri zapošljavanju nezaposlenih mladih osoba, sudionici ovog istraživanja ističu i neke potrebne promjene na razini obrazovnog sustava i tržišta rada, pa je tako dobivena kategorija učinkovitijeg usklađivanja obrazovanja te potreba na tržištu rada s pripadajućim kategorijama i pojmovima. Ono što sudionici mladi nezaposleni uočavaju je da je potrebno uvesti usklađivanje upisnih kvota na fakultetima ${ }^{76}$ te da je potrebno smanjiti dobnu neuravnoteženost ${ }^{77}$ na tržišstu rada.

\section{8}

„[...] Isto bi tako mogla biti neka podrška za mlade. Jer mislim da koliko god si ti mlad i da imaš i 20 godina, a ne 25 ili 28 , vjerujem da ta frustracija i ljutnja i to sve nakupljanje mjesecima u tebi ono može eskalirati jedan dan i čovjek ono može samo puknuti.“(S2).

69 „Na razgovorima za posao sam zaključila da mi je problem samopouzdanje. I onda, nisam svjesna toga da tiho pričam, i onda su mi rekli bili da se stekne krivi dojam o mojim sposobnostima na temelju moje prezentacije." (S22).

70 „Al najveći problem je znači to ne davanje prilika i to ograničenje zato što nemamo radno iskustvo. A kak ćemo ga mi i steć ako nam neko ne da priliku." (S8).

71 „[...] najveći problem mi je bio što svi nacionalni parkovi i parkovi prirode traže jednu godinu iskustva. Do sada nisam imao prilike, stručna osposobljavanja su dosta rijetka. Tako da sam se našao u tako nekom začaranom krugu." (S25).

72 „Recimo za ove radionice, to mi se čini super stvar jer poslodavci su rekli što njima treba i onda su ponudili takve radionice." (S22).

73 „I isto tako bi bilo dobro da tako pošto smo mi svi na burzi da imamo i ovako baš neku naknadu za nezaposlene..." (S8).

74 „To je druga strana priče što opet govorimo o svim porezima i zapravo svim nametima što zbog svih tih velikih nameta oni ne mogu uzeti ljude na stalno." (S6).

75 „Tako da sam odlučila da mi je sve to gubitak vremena i novca jer uvijek treba kopirati dokumente“ (22). 76 „Da uvedemo to da kako tržište reagira, tako mislim ne znam, te godine trebamo pet geologa, deset ekonomista i to upisati.“ (S23).

77 „Da imaju mogućnosti, prilike pokazat se, iskazat nekakve svoje mogućnosti jer je sistem takav da, em što sad žele da što starija populacija, što dulje radi, a mi nikako ne možemo upast' u taj sistem“ (S19). 
Nezaposleni mladi uočavaju da je potrebno mijenjati dijelove programa obrazovnog sustava kroz nekoliko bitnih segmenata, a to su veća kontrola terenske prakse ${ }^{78}$, zatim više terenske prakse u školama ${ }^{79}$ kao i uvođenje više sadržaja u škole radi pripreme za tržište rada $^{80}$. Pritom mladi smatraju da je potrebna i promjena programa u školama ${ }^{81}$ kao i uvođenje potpuno besplatnog obrazovanja ${ }^{82}$ te organizirana pomoć pri odabiru zanimanja ${ }^{83}$ kako bi mladi nakon završetka obrazovanja imali što bolju viziju mogućnosti svog radnog usmjerenja.

\section{Diskusija}

Praćenje i evidentiranje NEET populacije poseban je izazov, koji proizlazi iz njihovog ranjivog položaja. Nisu skloni biti u kontaktu s institucijama i njihovo povlačenje iz društva povlači rizik da postanu nevidljivi. ${ }^{84}$ Izazovi praćenja NEET populacije već su dijelom istaknuti u hrvatskom okruženju (Tomić i sur., 2018.) te ih ovo istraživanje iz pozicije mladih i stručnjaka dodatno naglašava. ${ }^{85}$ Nedostatak podataka o specifičnostima te populacije i njihovim potrebama u svrhu što kraćeg zadržavanja u statusu nezaposlenih onemogućuje i ciljane mjere, posebno u segmentu aktivacijske politike (Tomić i sur., 2018.).

Bitnim se pokazuje i usmjeravanje posebne pozornosti prema NEET populaciji u institucijama i pružanje ciljanih, svrhovitih i pravovremenih usluga, što zahtijeva resurse

78 „Lako je to na praksi, ljudi ne znaju šta mi uopće radimo, šta ne. Je da pišemo dnevnike, al opet kak ćeš ti to znat da smo mi to radili il ne."(S3).

79 „[...] slažem se s kolegom da bi trebalo imat više prakse i da ovo nije uopće dovoljno da bi počeli radit" $(\mathrm{S} 10)$.

80 „Za institucije obrazovanja mislim da definitivno treba ubaciti više praktičnog rada i informacije, da nas se informira o tržištu, nekim općenitim gospodarskim stvarima, procesima jer je sa s takvim stvarima nikada nisam susrela, nitko me nikad nije uputio“" (S18).

81 „Znači najbitnije je ovo, osnovne stvari da znamo općenito kulturno i ovako znači što se tiče samih struka, a ne nepotrebne informacije koje nam nikad ništa ne će značiti i koje oni tjeraju da se buba na pamet." (S8).

82 „[...] bi trebalo bit pokrenuto na besplatno obrazovanje jer mislim da je to dosta da kažemo manjak za možda čak i neke buduće studente“ (S5).

83 „Nema nekih informacija, nitko vam ne govori u srednjoj školi što sve postoji, što se sve uopće može raditi." (S21).

${ }^{84}$ Hrvatski zavod za zapošljavanje posjeduje podatke samo o registriranim nezaposlenim osobama različitih dobnih skupina, što znači da u Hrvatskoj postoje samo administrativni podaci o nezaposlenom dijelu NEET populacije, dok o onom koji nije aktivan na tržištu rada, odnosno ne traži posao putem Hrvatskog zavoda za zapošljavanje ne postoje adekvatne informacije.

$\mathbf{8 5}$ Podaci o registraciji te populacije pri zavodima za zapošljavanje pokazuju da je svega $57 \%$ te populacije u EU-u registrirano pri takvim zavodima (Eurofound, 2016.). 
i stručnjake usmjerene specifično prema realizaciji napora koje država treba uložiti kad je ta populacija u pitanju. ${ }^{86} \mathrm{U}$ trenutnoj perspektivi, stručnjaci koji rade s NEET populacijom naglašavaju nedostatak vremena i resursa za rad s njima, a i mladi vide da se stručnjaci nedovoljno i s neadekvatnom pozornošću bave njima ${ }^{87}$. Primjerice, što se tiče Centara za socijalnu skrb, učestalost zakonodavnih izmjena te promjene i neujednačenost u organizaciji rada čine sustav socijalne skrbi po pitanju učinkovitosti mjera i informiranja nedovoljno sigurnim i za korisnike i za socijalne radnike (Ilijaš i Podobnik, 2018. $)^{88}$.

Oslobađanje prostora za rad stručnjaka čini se vitalnim. Stoga je potrebno napraviti preorijentaciju u radu s NEET populacijom, jer stručnjaci upozoravaju da je motiviranje i prikladno informiranje mladih velik izazov. ${ }^{89}$ Mentorski rad, ali i promjena načina komunikacije, koja bi bila suvremenija i bliža habitusu mladih, predstavljali bi pozitivnu promjenu. No napori trebaju početi puno ranije, primjerice kao preventivni rad usmjeren na školsko okruženje, vršnjačku okolinu, lokalnu zajednicu i život u obitelji.

Programi prevencije i integracije NEET populacije na tržište rada i u društvo trebaju biti, prema mišljenju stručnjaka i mladih, usmjereni specifičnijim edukacijama za mlade u svrhu učenja vještina za zapošljavanje ili za stjecanje zanimanja koja su tražena na tržištu rada. Potrebna je i rana prevencija dugotrajne nezapošljivosti mladih. Za ranu prevenciju jedan je od ključnih elemenata suradnja različitih dionika već u osnovnoj školi, radi prepoznavanja rizika od ulaska u NEET status i pružanje odgovarajuće potpore.

Kako bi provođenje politike zapošljavanja u praksi imalo značajnije učinke, potrebno je u većoj mjeri ulagati u Hrvatski zavod za zapošljavanje (HZZ). Oni se ne bave samo analizom, procjenama i predviđanjima budućih potreba na tržištu nego i savjetodavnim radom s nezaposlenim osobama90. Mladi sada nalaze brojne zamjerke na rad

86 Da državne (obrazovne i socijalne) institucije i službe ne nude adekvatnu pomoć mladima u zapošljavanju izazov je koji se prepoznaje već duži niz godina (Koller-Trbović, Žižak i Jeđud, 2009.). Nedavno (Kovaćić i Gvozdanović, 2017.) ustanovljuju da je glavna mjera za rješavanje problema mladih vezana za obrazovnu politiku i politiku zapošljavanja.

87 Također, raspolaže se oskudnim pokazateljima kvalitete usluga koje se pružaju korisnicima (Ilijaš i Podobnik, 2018.).

88 Autori (Ilijaš i Podobnik, 2018.) također navode kronični manjak radnika kao problem, a za one koji rade u sustavu (Družić Ljubotina i Frišćić, 2014.) navode različite potencijalne izvore stresa kod socijalnih radnika.

89 Povećanje izdvajanja za informiranje mladih jedna je od preporuka u tom kontekstu (Kovačić i Gvozdanović, 2017).

90 I prijašnja istraživanja sugeriraju ograničenja HZZ-a u komuniciranju s nezaposlenima i njihovom informiranju (Koller-Trbović, 2009.). 
Zavoda, a i stručnjaci su jednim dijelom kritični prema sebi. Naravno, uz to postoje i zadatosti institucija u vidu ograničenog vremena za rad s korisnicima i resursa kao i ustroja samih institucija.

U kontekstu unaprjeđenja uvjeta zapošljavanja NEET populacije stručni suradnici navode prepreke poput nedostatne koordinacije rada $s$ drugim institucijama i dionicima koji djeluju u tom području. Manjak koordinacije i sustavnosti rada institucija prepoznat je i u drugim istraživanjima (Šverko, Galić i Maslić Seršić, 2006.; KollerTrbović, 2009.). Udruge i njihovi brojni programi koje provode s ciljem pripremanja mladih za zahtjevno tržište rada nisu još prepoznati od stručnjaka. Oni nisu upoznati ni s modelom kombinirane socijalne politike i potrebama veće suradnje s drugim dionicima u ostvarivanju socijalne dobrobiti.

Slijedom toga javlja se potreba za socijalnim inovacijama unutar i van institucija, posebice u okviru dostupnih usluga. Europski fondovi donose sve veće mogućnosti za razvoj programa za NEET populaciju u organizacijama civilnog društva, zasebno ali zasigurno i uz veće sinergijske učinke u programima koji bi bili u partnerstvu s drugim stručnjacima i institucijama i inicijativama koje rade s NEET populacijom. Neke od prilika već su propuštene, primjerice otvaranje prostora i razvoj aktivnosti za socijalno i radno uključivanje mladih zbog slabo implementirane Strategije razvoja društvenog poduzetništva 2015. - 2020. (Vlada RH, 2015.).

Nameće se potreba bolje koordinacije i veće sustavnosti rada, posebice u hrvatskom kontekstu, u kojem su usluge povezane sa socijalnim uključivanjem i uključivanjem na tržište rada još uvijek relativno nerazvijene. Prijašnja istraživanja o kombiniranoj socijalnoj politici sugeriraju da javni sektor nema dovoljno kapaciteta za suradnju s organizacijama civilnog društva i drugim dionicima u socijalnoj politici (Bežovan, 2009.; Bežovan, 2010.), iako postoje određeni pozitivni pomaci potaknuti jednim dijelom i suradnjom na EU projektima.

U kontekstu hrvatske socijalne politike postoji određeni dualizam socijalnih prava između zaposlenih i osoba u mirovini koje imaju socijalna prava i onih van svijeta rada koji su socijalno isključeni, a kojima pripada i NEET populacija. Za njih se izdvaja malo sredstava. ${ }^{91}$ Takve je podjele dodatno istaknula ekonomska kriza, koja je pokazala da Hrvatska nije usmjerena na aktivaciju ili socijalna ulaganja u mlade (Dobrotić, 2016.; Babić i Baturina, 2016.). Pri tome je značajan kontinuitet rada, a ne isprekidanost projektno financiranih inicijativa, koje postaju obilježje djelovanja, posebno potaknuto karakterom projektnog financiranja projekata i programa sredstvima iz Europskih fondova (Baturina, 2016.). ${ }^{92}$

91 Primjerice za 2018 godinu Hrvatska unutar ukupnih troškova za socijalnu zaštitu za funkciju nezaposlenosti izdvaja 0,5\% BDP-a, dok je prosjek na razini EU-a 1,3\% BDP-a (Eurostat, 2020.b).

92 U budućnosti se za integraciju mladih na tržište rada i strukturne reforme prema tome očekuju značajna sredstva Europskog socijalnog fonda plus. 


\section{Umjesto zaključka}

Ovaj rad u središte znanstvenog interesa stavlja izazove NEET populacije s kojima se suočava tijekom traženja zaposlenja i prevladavanja određenih prepreka u zadovoljavanju uvjeta tržišta rada. Radi se o populaciji koja je u hrvatskoj znanstvenoj i stručnoj javnosti nedovoljno prepoznata kao rizična skupina društva i koja je zbog poteškoća sa zapošljivošću izložena riziku od socijalne isključenosti i siromaštva. Radi se ujedno i o populaciji koja je „nevidljiva“ i nesklona traženju usluga različitih institucija koje pružaju podršku nezaposlenim mladima.

Istraživanje je, što je bitno za kontekst, provedeno u nadprosječno razvijenoj lokalnoj zajednici $s$ resursima i obuhvatom lokalnih socijalnih politika koje premašuju mogućnosti drugih lokalnih zajednica. No i u takvom kontekstu rezultati istraživanja ukazuju na ograničene resurse koje stručnjaci imaju na raspolaganju u svom radu, ali i izazove reformi samih institucija kako bi svojim načinom rada te ponudom programa i tipa stručne potpore bili privlačniji mladim osobama. To se posebno tiče onog dijela NEET populacije koji zazire od ulaska u institucije i traženja usluga i suradnje s njima.

U tim aspektima pomoć mogu pružiti i organizacije civilnog društva, poput klubova mladih, koji pružaju mladima više prostora za vlastiti angažman. Uz kvalitetnu međusektorsku suradnju očekuje se da se mladima, posebno onima u nepovoljnom položaju, ponudi više prilika da aktivno sudjeluju u sukreaciji i suprodukciji usluga namijenjenih njima. Socijalno-poduzetničke inicijative ${ }^{93}$ i jačanje sposobnosti mladih za samoktivaciju neke su od mogućnosti zadovoljavanja potrebe mladih za podrškom u traženju zaposlenja.

U tom pogledu razvoj usluga u zajednici, u ovom slučaju aglomeracije Grada Zagreba, koje bi bile prepoznatljive i bliske mladim ljudima mogu biti zalog socijalnog uključivanja NEET populacije. Stručni se rad dijelom treba izmaknuti iz institucija i približiti se mladima na razini lokalne zajednice (gradske četvrti) i iskoristiti njene stručne i prostorne resurse ili potaknuti stvaranje novih, primjerice osnivanje organizacije civilnog društva s ciljem pružanja programa podrške nezaposlenim mladima. Time se dijelom može odgovoriti na pitanje kako pristupiti onima koji su najobeshrabreniji i nevidljivi. Ekosustav socijalnih inovacija (Baturina, 2019.) trebalo bi dodatno osnažiti kako bi se eksperimentiralo s novim načinima uključivanja i oblicima učenja i stjecanja vještina mladih osoba. Europski socijalni fond i budući Europski socijalnih fond plus u nedostatku javnih izdvajanja ostaju okvir za promišljanje novih ideja. Neke od pozitivnih aspekata aktivnih politika tržǐ̌ta koje su prepoznate u istraživanju trebalo bi nadopuniti aktivnijim stručnim radom.

93 Potencijal socijalnog poduzetništva u području socijalne politike je prepoznat, ali za sada nedovoljno iskorišten (Baturina, 2018.). 
Za sada ne postoji značajnije usmjerenje na pružanje glasa mladima u politici i društvu, te, nažalost, možemo reći da postoji generacijski problem nebrige društva o mladima (Kovačić i Gvozdanović, 2017.). Jedan od aktivnih primjera kojim se može doprinijeti rješavanju generacijskog problema Nacionalni je program za mlade. No on je donesen za razdoblje do 2017. godine, a početkom 2020. godine i dalje nije donesen novi. To je jedan od eklatantnih primjera važnosti koju politika pridaje mladima. NEET populacija unutar šire skupine mladih u posebice je teškom položaju. Bez većeg prepoznavanja važnosti mladih u društvu koje je sve starije i u kojem brojni mladi iseljavaju ili razmišljaju o emigraciji, teško je očekivati veća ulaganja i osiguravanja prostora za stručni rad. Jačanje institucija iznutra, njihovo učinkovito međuresorno povezivanje, međusektorska suradnja i koordinacija s resursima lokalne zajednice koji se bave nezaposlenim mladima mogu biti zalog unapređenju rada s NEET populacijom. Osim toga, davanje prostora stručnjacima za djelovanje, uvažavanje njihovih smjernica za poboljšanje kvalitete usluga i razvoj inovativnih ideja u zajednici mogli bi biti koraci ka ostvarivanju održivih, dobrih ishoda u radu s NEET populacijom i kroz njihovu dugotrajnu zapošljivost.

\section{Literatura}

1. Babić, Z. i Baturina, D. (2016). Koncept socijalnih investicija kao odgovor na krizu i nove izazove socijalne države: trendovi i perspektiva. Revija za socijalnu politiku. 23 (1): 61-80.

2. Babić, Z. and Baturina, D. (2019). Social Plan of the City of Zagreb 20142020: "What Is Planned and what sas Been achieved?" Preparatory study for the Social policy, jobs \& growth - Croatia - Croatian Science meet regions event, held in Zagreb, Croatia 17.10.2019. Brussels: European Commission Joint Research Centre.

3. Baturina, D. (2016). Utjecaj trećeg sektora na socio-ekonomski razvoj Republike Hrvatske (doktorska disertacija). Zagreb: Pravni fakultet Zagreb.

4. Baturina, D. (2018). First Strategy for the development of Social Entrepreneurship in the Republic of Croatia and potentials for the development of the sector. Croatian and Comparative Public Administration, 18 (2): 11-39.

5. Baturina, D. (2019). The struggles of shaping social innovation environment in Croatia. Annals for Istrian and Mediterranean Studies - Series Historia et Sociologia, 29 (2): 323-334.

6. Baturina, D.; Majdak, M. and Berc, G. (2016). Framing the problem and challenges of dropouts in Croatia: Invisible people around us but not us, in: Sundby, R. and Heimgartner, A. (Eds.). The Welfare Society - an Aim for Social Development. Wien: Lit Verlag, GmbH \& Co, KG, 109-127.

7. Bedeniković, I. (2017). (Ne) zaposlenost mladih i NEET populacija u Hrvatskoj. Mali Levijatan:studentski časopis za politološke teme, 4 (1): 75-90. 
8. Bejaković, P.; Dedić, D.; Desović, P.; Ivišić, J.; Mikić, I.; Penezić, L.; Šeparović, M. (2016). Vanjska evaluacija mjera aktivne politike tržišta rada 2010. - 2013. Zagreb: Hrvatski zavod za zapošljavanje. https://www.hzz.hr/UserDocsImages/ HZZ i Ipsos Vanjska-evaluacija-mjera-aktivne-politike-trzista-rada 2010.pdf

9. Berc, G.; Bežovan, G. i Majdak, M. (2015). Perspektiva stručnih suradnika o ispadanju učenika iz srednjih škola kao novom socijalnom problemu. Revija za socijalnu politiku, 24 (1): 1-31.

10. Bežovan, G. (2009). Civilno društvo i javna uprava kao dionici razvoja kombinirane socijalne politike u Hrvatskoj. Hrvatska javna uprava: časopis za teoriju i praksu javne uprave, 9 (2): 355-391.

11. Bežovan, G. (2010). Postignuća i izazovi razvoja kombinirane socijalne politike u Hrvatskoj, 2010. (istraživački izvještaj). Zagreb: CERANEO.

12. Bežovan, G. (2019). Hrvatska socijalna politika u vremenu globalizacije i europeizacije, u: Bežovan, G.; Puljiz, V.; Šućur, Z.; Babić, Z.; Dobrotić, I.; Matković, T.; Zrinščak, S. (Ur.). Socijalna politika Hrvatske, II. izdanje, Zagreb: Pravni fakultet Sveučilišta u Zagrebu.

13. Bilić, N. i Jukić, M. (2014). Nezaposlenost mladih-ekonomski, politički i socijalni problem s dalekosežnim posljedicama za cjelokupno društvo. Pravni vjesnik: časopis za pravne i društvene znanosti Pravnog fakulteta Sveučilišta Josip Juraj Strossmayera u Osijeku, 30 (2): 485-505.

14. Bruno, G. S.; Marelli, E. and Signorelli, M. (2014). The rise of NEET and youth unemployment in EU regions after the crisis. Comparative Economic Studies, 56 (4): 592-615.

15. Buković, N. (2012.) Tko se boji velike zločeste krize? Strukturirani dijalog o nezaposlenosti mladih. Proces, metodologija $i$ rezultati. Zagreb: Mreža mladih Hrvatske.

16. CERANEO (2019). Izazovi provedbe smjernica Europskog stupa socijalnih prava u Gradu Zagrebu. Komparativna socijalna slika grada Zagreba za 2017. i 2018. godinu. Zagreb: CERANEO.

17. Dobrotić, I. (2016). Crisis and Croatian welfare state: a new opportunity for welfare state retrenchment?, in: Schubert Klaus, Paloma de Villota, Johanna Kuhlmann (Eds.). Challenges to European Welfare Systems. New York: Springer Publishing, 301-324.

18. Družić Ljubotina, O. i Friščić, Lj. (2014). Profesionalni stres kod socijalnih radnika: izvori stresa i sagorijevanje na poslu. Ljetopis socijalnog rada, 21 (1): 5-32. https:// doi.org/10.3935/ljsr.v21i1.10

19. Državni zavod za statistiku Republike Hrvatske (2019). Statističke informacije 2019. https://www.dzs.hr/Hrv Eng/StatInfo/pdf/StatInfo2019.pdf

20. Eurofound (2016). Exploring the diversity of NEETs. Luxembourg: Publications Office of the European Union.

21. Eurostat (2013). Glosary: Early leaverfrom education and training. http://epp. eurostat.ec.europa.eu/statistics_explained/index.php/Glossary:Early_school_ leaver 
22. Eurostat (2019a). Statistics on young people neither in employment nor in education or training. https://ec.europa.eu/eurostat/statistics-explained/index.php/ Statistics on young people neither in employment nor in education or training. (Pregledano 29.11.2020.)

23. Eurostat (2019b). File: Young people (aged 20-34) neither in employment nor in education and training, by sex and age, 2019 (\%).png. https:// ec.europa.eu/eurostat/statistics-explained/index.php?title=File:Young_people (aged 20\%E2\%80\%9334) neither_in_employment_nor_in_education_and training, by sex and age, 2019 (\%25).png. (Pregledano 29.11.2020.)

24. Eurostat (2020.a). Young people neither in employment nor in education and training by sex, age and labour status (NEET rates)[edat_lfse_20] last update: 21-04-2020 https://appsso.eurostat.ec.europa.eu/nui/show.do?dataset=edat lfse 20\&lang=en. (Pregledano 12.6.2020.)

25. Eurostat (2020.b). General government expenditure in the EU in 2018. https:// ec.europa.eu/eurostat/documents/2995521/10474879/2-27022020-AP-EN. pdf/4135f313-1e3f-6928-b1fd-816649bd424b. (Pregledano 12.11.2020.)

26. Ferić, I.; Milas, G. and Rihtar, S. (2010). The reasons and determinantes of early school leaving, Društvena istraživanja, 19 (4-5): 621-642.

27. Grad Zagreb (2014). Socijalni plan Grada Zagreba 2014. - 2020. Zagreb: Grad Zagreb.

28. Hsieh, H. and Shannon, S. E. (2005). Three approaches to qualitative content analysis. Qualitative health research, 15 (9): 1277-1288.

29. Ilijaš, A. i Podobnik, M. (2018). Nestabilnost zakona o socijalnoj skrbi - kako utječe na rad socijalnih radnika u centrima za socijalnu skrb? Ljetopis socijalnog rada, 25 (3): 527-450.

30. Koller-Trbović, N. (2009). Nezaposlenost u doživljaju i iskustvu nezaposlenih mladih u Hrvatskoj. Ljetopis socijalnog rada, 16 (1): 111-131.

31. Koller-Trbović, N.; Žižak, A. i Jeđud, I. (2009). Nezaposlenost i socijalna isključenost mladih u Hrvatskoj: perspektiva nezaposlenih mladih u riziku ili s poremećajima u ponašanju. Kriminologija i socijalna integracija, 17 (2): 87-103.

32. Kovačić, A. i Gvozdanović, A. (2019). Poznavanje generacijskih problema i potreba kao temelj kvalitetne politike za mlade u Hrvatskoj, u: Ilišin, V. i Spajić Vrkaš, V. (Ur.). Generacija osujećenih: mladi u Hrvatskoj na početku 21. stoljeća. Zagreb: Biblioteka Znanost i društvo (40) Institut za društvena istraživanja.

33. Matković, T. (2019). Politike zapošljavanja i nezaposlenost, u: Bežovan, G.; Puljiz, V.; Šućur, Z.; Babić, Z.; Dobrotić, I.; Matković, T.; Zrinščak, S. (Ur.). Socijalna politika Hrvatske, II. izdanje, Zagreb: Pravni fakultet Sveučilišta u Zagrebu.

34. Matković, T. (2010). Parent education, econimic status and early school leaving in Croatia: trends over the past decade. Društvena istraživanja, 19 (4-5): 643-667.

35. Milas, G. i Ferić, I. (2009). Does extended Compulsory Education give an influence on Reducing the Droupout Rates? Društvena istraživanja, 18 (4-5), 649-671. 
36. Ministarstvo za demografiju, obitelj, mlade i socijalnu politiku (2020). Nacrt Nacionalni program za mlade za razdoblje od 2020. do 2024. godine. Zagreb: MDOMSP.

37. Ministarstvo za demografiju, obitelj, mlade i socijalnu politiku (2014). Nacionalni program za mlade za razdoblje od 2014. do 2017. Zagreb: Ministarstvo za demografiju, obitelj, mlade i socijalnu politiku.

38. MRMS, (2019.a). Izvješće o provedbi Plana implementacije Garancije za mlade u 2018. Zagreb: MRMS.

39. MRMS, (2019.b). Plan implementacije Garancije za mlade 2019-2020. Zagreb: MRMS.

40. Novosel, T.; Preveden, A. i Buković, N. (2015). Garancija za sve mlade: Mladi iz aternatiune skrbi na marginama garancije. Zagreb: Mreža mladih Hrvatske

41. Obiteljski zakon, Narodne Novine 103 od 2015.

42. Operativni program-učinkoviti ljudski potencijali 2014. - 2020 (2014). http:// www.esf.hr/wordpress/wp-content/uploads/2015/09/OPULJP-hr-20150709. pdf. (Pregledano 20.6.32020.)

43. Potočnik, D. i Spajić-Vrkaš, V. (2017). Mladi u Hrvatskoj: sudjelovanje na tržištu rada i prostorna mobilnost, u: Ilišin, V. i Spajić Vrkaš, V. (Ur.). Generacija osujećenih: mladi u Hrvatskoj na početku 21. stoljeća. Zagreb: Biblioteka Znanost i društvo (40) Institut za društvena istraživanja.

44. Ritchie, J. and Spencer, L. (1994). Qualitative data analysis for applied policy research, in: Bryman, A. and Burgess, R. (Eds.). Analyzing Qualitative Data. London: Routledge.

45. Savjet mladih Grada Zagreba (2016). Izvješće o provedenom ispitivanju mišljenja i potreba mladih u Gradu Zagrebu. Zagreb: Savjet mladih Grada Zagreba

46. Šverko, B.; Galić, Z. i Maslić Seršić, D. (2006). Nezaposlenost i socijalna isključenost: longitudinalna studija. Revija za socijalnu politiku, 13 (1): 1-14.

47. Tomić, I.; Botrić, V. i Žilić, I. (2018). Analiza stanja i preporuke za razvoj daljnjih aktivnosti za osobe u NEET statusu. (projektna studija). Zagreb: Ministarstvo rada i mirovinskoga sustava.

48. Vlada RH (2014). Strategija borbe protiv siromaštva i socijalne isključenosti u Republici Hrvatskoj (2014. - 2020.). Zagreb: Vlada RH.

49. Vlada RH (2015). Strategija razvoja društvenog poduzetništva 2015-2020. Zagreb: Vlada RH. 


\title{
Perspective of the NEET Population in the Urban Agglomeration of Zagreb According to the Perception of Professional Experts and Youth in the NEET Status - How to Help Them?
}

\author{
Danijel Baturina \\ University of Zagreb, Faculty of Law, Social Work Study Centre, Croatia \\ e-mail: danijel.baturina@pravo.hr \\ Marijana Majdak \\ University of Zagreb, Faculty of Law, Social Work Study Centre, Croatia \\ e-mail: marijana.majdak@pravo.hr

\section{Gordana Berc} \\ University of Zagreb, Faculty of Law, Social Work Study Centre, Croatia \\ e-mail: gordana.berc@pravo.hr
}

\begin{abstract}
Due to the large representation of the NEET population, in 2013 the European Union drafted the Operational plan to reduce the share of this population for the period 2014-2020. In Croatia, ESF measures and funds are also planned. The City of Zagreb as a part of investing in social policy, develops numerous services and programs for young people in unfavorable social position. This qualitative research is aimed at gaining insight into the experiences of experts and members of the NEET population on services and programs aimed to the NEET population in the City of Zagreb in order to prepare them for employment and also on the perception of possible service improvement and prevention of NEET status. The study involved 15 experts working with the NEET population and 25 members of the NEET population. The results suggest that experts recognize the challenges in working with the NEET population in terms of motivating young people to the change and in terms of demanding work models. In addition, institutional limitations such as insufficient coordination with other institutions, administrative constraints and insufficient professional training of experts are highlighted by both groups of research participants. Young people emphasize that some services and information that they receive from professionals are useless and late, and on the other side that they have positive experiences in obtaining professional recommendations and personal support. The research indicates the need for systematic investment in institutions that work with NEET population (staff, space, informatization, coordination of institutions) in the City of Zagreb. Besides, there are highlighted needs of improvement of the content and work model of programs as well as investment in promotion and availability of support programs for the NEET population to enter the labor market.
\end{abstract}

Key words: NEET population, experts, urban agglomeration Zagreb, social policy, unemployment, programs and measures to NEET population employment. 